CZASOPISMO INŻYNIERII LA¿OWEJ, ŚRODOWISKA I ARCHITEKTURY JOURNAL OF CIVIL ENGINEERING, ENVIRONMENT AND ARCHITECTURE JCEEA, t. XXXIV, z. 64 (4///17), październik-grudzień 2017, s. 87-101, DOI:10.7862/rb.2017.195

\author{
Marek GOSZTYLA ${ }^{1}$ \\ Stanislaw LEŚ $\dot{S}^{2}$ \\ Krystian SIKORSKI ${ }^{3}$
}

\title{
STARY RYNEK W RZESZOWIE - TYNKI STOSOWANE W PROCESIE RENOWACJI OBIEKTÓW ZABYTKOWYCH. ASPEKTY TECHNOLOGICZNE
}

\begin{abstract}
Rynek jako wizytówka miast jest miejscem o istotnych walorach kulturowych, a jego stan jest odzwierciedleniem potencjału i rangi ośrodków. W związku z tym faktem, niebywałą uwagę przykłada się do estetyki, najczęściej historycznej zabudowy okalającej płytę główną. Główny wpływ na stan techniczny frontowych elewacji śródmiejskich kamienic ma jakość wykonanych robót i użytych materiałów, co związane jest bezpośrednio z czteroetapowym systemem diagnozy, naprawy i użytkowania obiektu. Wspomnieć należy, iż prawidłowe rozpoznanie zależności przyczynowo skutkowej jest zagadnieniem kluczowym w przypadku właściwego wykonania prac konserwatorskich. W artykule zwrócono uwagę na celowość stosowanych pokryć elewacji na przykładzie rzeszowskiego Starego Rynku, którego zabudowa w ostatnich latach poddana została szeregowi prac związanych z poprawą istniejącego stanu technicznego. Pod rozważania poddano kilka rodzajów tynków używanych podczas wykonywania prac konserwatorskich związanych z zabezpieczeniem obiektu. Wśród nich wymienić należy tynki wapienne, cementowe, cementowo - wapienne oraz renowacyjne. Na podstawie wykonanych badań stwierdzono stan obecny obiektów referencyjnych, co pozwoliło sformułować wnioski dotyczące przydatności zastosowanych rozwiązań. Jedynie tynki renowacyjne umożliwiły spełnienie założeń projektowych, tj.: wpłynęły na obniżenie zawartości wilgoci w przegrodach. Bezsprzeczną zaletą tynków renowacyjnych, wynikającą z ich składu oraz struktury, jest kumulowanie soli wewnątrz porów, co przekłada się na ich wysoką trwałość (nie stwierdzono odparzania lub odspajania tynku od powierzchni muru). Dodatkowo w artykule poruszono zagadnienia związane z poprawnością wykonania prac konserwatorskich oraz wpływem doboru materiałów na trwałość wykonanych pokryć elewacji.
\end{abstract}

Słowa kluczowe: Rzeszów, Stary Rynek, tynk renowacyjny, wilgotność, sole budowlane

\footnotetext{
${ }^{1}$ Autor do korespondencji / corresponding author: Marek Gosztyła, Politechnika Rzeszowska, Katedra Konserwacji Zabytków, ul. Powstańców Warszawy 12, 35-959 Rzeszów, gosztyla@prz.edu.pl

${ }^{2}$ Stanisław Leś, Technolog PCI, stanisław.les01@gmail.com

${ }^{3}$ Krystian Sikorski, doktorant WBIŚiA PRz, mr.krystian.sikorski@gmail.com
} 


\section{Wstęp}

Każda osada ludzka posiada sieć naczyń zwanych ulicami, które prowadzą do miejsca centralnego - rynku. Funkcja rynku na przestrzeni wieków ulegała zmianom. Zawsze jednak, bez względu na zjawiska i procesy społecznopolityczne, miejsce to było wyjątkowe. Stanowiło centrum życia kulturowego i społecznego, było miejscem wymiany towarów i zwyczajów. To właśnie te zjawiska warunkowały napływ możnych kupców, którzy kierując się perspektywą rozwoju budowali tu swe domostwa - kamienice. Upływający czas, a wraz z nim zmiany wizji architektonicznej powodowały ewolucję zabudowy okalającej rynek.

Ze względu na wiek oraz wartość architektoniczną kamienice stanowią ważny element zabudowy śródmiejskiej, a jako obiekty objęte ochroną konserwatorską wymagają poświęcenia im szczególnej uwagi. Powszechną praktyką, wynikającą z reprezentatywnej funkcji zabudowy, związaną z utrzymaniem dobrego stanu technicznego, a także estetyki jest dbanie m.in. o frontową elewację. (Przez dbanie rozumieć należy brak możliwości ingerencji w wygląd elewacji sytuacją nie do pomyślenia jest skucie elementów ozdobnych celem wykonania zabezpieczenia termicznego przy użyciu styropianu, co w przypadku elewacji od strony podwórza jest praktyką częstą, na która zazwyczaj przyzwala konserwator zabytków). Warunkiem niezbędnym i koniecznym związanym z powyższym zagadnieniem jest dobór odpowiednich materiałów i systemów naprawczych, które zastosowane w sposób zgodny z przeznaczeniem gwarantują zabezpieczenie elementów konstrukcyjnych, a przez to poprawę stanu istniejącego.

Wiadomym jest, iż każdy obiekt budowlany narażony jest na oddziaływanie środowiska, głównie nieustannie krążącej wody, która napiera z każdej możliwej strony. Aby zapobiec powstawaniu niekorzystnych zjawisk spowodowanych nadmiernym zawilgoceniem, a wraz $\mathrm{z}$ nim zasoleniem budynku, niezbędnym jest odcięcie dopływu wody do elementów konstrukcyjnych. W tym celu wykonywane są odpowiednie zabezpieczenia, zapobiegające wnikaniu wody w głąb struktury materiału. Pytanie brzmi: jakie kroki należy przedsięwziąć jeśli stwierdzono nieodpowiednia izolację lub, jak często bywa w przypadku obiektów zabytkowych, jej brak. Pierwszym krokiem powinno być wykonanie odpowiednich zabiegów mających na celu odcięcie dalszego dopływu wody. Aktualnym pozostaje jednak problem nadmiaru wilgoci oraz soli budowlanych, uprzednio zmagazynowanych wewnątrz struktury materiałów wchodzących w skład konstrukcji. Sprawdzonym rozwiązaniem jest wykonanie kompleksowej renowacji z zastosowaniem tynków renowacyjnych. W niniejszym artykule obiektem badań są kamienice usytuowane na rzeszowskim Starym Rynku, których elewacje zostały odnowione w przeciągu kilku ostatnich lat. Przedmiotem przeprowadzonych badań jest sprawdzenie celowości zastosowanych rozwiązań. 


\section{Stosowane materiały}

Właściwy dobór tynku ma znaczący wpływ na późniejszy stan techniczny, a co za tym idzie estetykę obiektu. Prawidłowym przykładem jest stosowanie tynków renowacyjnych ze względu na szereg właściwości, wśród których wyróżnić należy zwiększoną porowatość i dyfuzyjność. W praktyce często spotykanym zwyczajem jest zastępowanie tychże tynków innymi tynkami. Materiałem stosowanym $\mathrm{w}$ zastępstwie są tynki wapienne, cementowe lub wapienno cementowe, które nie są w stanie sprostać napierającej wodzie oraz solom mineralnym, a co za tym idzie zapewnić trwałości wykonanym w ten sposób pokryciom elewacji.

Pierwszym rodzajem tynków stosowanych przy pracach konserwatorskich są, uważane za spoiwo historyczne, tradycyjne tynki wapienne. Mają one największą podatność na zniszczenie poprzez procesy związane z przedostawaniem się rozpuszczonych soli mineralnych. Ma to bezpośredni związek z ich strukturą, która umożliwia wzmożone podciąganie kapilarne. Czynnikami eliminującymi ten rodzaj tynku są wysoka nasiąkliwość i chłonność wilgoci z powietrza [3].

Tynki cementowe w przeciwieństwie do wapiennego odpowiednika charakteryzują się wyższą wytrzymałością na uszkodzenia mechaniczne. Ze względu na pory o bardzo małej powierzchni szybko ulegają zawilgoceniu, co przy założeniu współistnienia soli doprowadzi do ich krystalizacji powodując tym samym zmniejszenie powierzchni porów i utrudnione odparowywanie zgromadzonej wody [1].

Ostatnimi niespełniającymi standardów tynkami, spotykanymi w przypadku prac renowacyjnych są tynki cementowo - wapienne. Charakteryzują się poprawionymi właściwościami w stosunku do tynków wapiennych oraz cementowych. Podobnie jednak jak wyżej wymienione tynki nie są przydatne w przypadku zawilgoconych murów, gdyż posiadają małą zdolność do akumulacji soli, a także są słabo dyfuzyjne [2].

Środkiem łączącym przydatne cechy tynku cementowo - wapiennego z polepszonymi parametrami przyczyniającymi się do samoosuszania muru są tynki renowacyjne. Posiadają one w swej strukturze dużą ilość porów (świeża zaprawa $>25 \%$, stwardniała $>40 \%$ ), dzięki czemu mogą skutecznie akumulować sole wewnątrz swej struktury, jednocześnie nie obniżając estetyki elewacji. Dodatkowo tynki renowacyjne posiadają współczynnik oporu dyfuzyjnego na poziomie $\mu \leq 12$, co zapewnia migrację pary wodnej (z muru do otoczenia) przy jednoczesnym koncentrowaniu wilgoci i soli budowlanych w przypowierzchniowych warstwach muru [6].

W celu uzyskania najlepszego możliwego efektu nie wystarczy jedynie zastosować tynk renowacyjny z aprobatą organizacji Naukowo-Technicznej Grupy Roboczej ds. Utrzymania Budowli i Ochrony Zabytków. Pomijając potrzebę odcięcia muru od dalszego dopływu wilgoci (izolacja pionowa i poziome) pamiętać należy, iż system uwzględnia wykonanie poszczególnych warstw (obrzutka, tynk podkładowy, tynk renowacyjny) we współpracy z materiałami dodatkowymi (preparat do neutralizacji soli, szpachlę wygładzającą, farby do wymalowań) w zależności od poziomu zasolenia muru. Tabele 1 i 2 ilustrują poziomy zasolenia i zależne od nich układy warstw. 
Tabela 1. Klasyfikacja stopnia zasolenia muru. Systemy PCI do renowacji i izolowania zawilgoconych budynków

Table 1. Graduation of wall salinity, PCI solutions

\begin{tabular}{|c|c|c|c|c|}
\hline \multicolumn{2}{|c|}{ Rodzaj soli } & \multicolumn{3}{c|}{ Zawartość soli [\%] } \\
\cline { 3 - 5 } & $\mathrm{Cl}^{-}$ & Niski & Średni & Wysoki \\
\hline Chlorki & $\mathrm{SO}_{4}^{-2}$ & $<0,2$ & $0,2-0,5$ & $>0,5$ \\
\hline Siarczany & $\mathrm{NO}_{3}^{-2}$ & $<0,5$ & $0,5-1,5$ & $>1,5$ \\
\hline Azotany & & $0,1-0,3$ & $>0,3$ \\
\hline
\end{tabular}

Tabela 2. Grubości warstw tynku renowacyjnego w zależności od stopnia zasolenia muru. Systemy PCI do renowacji i izolowania zawilgoconych budynków

Table 2. Thickness of renovation plaster regarding to wall salinity, PCI solutions

\begin{tabular}{|c|c|c|}
\hline Stopień skażenia muru & Układ warstw & Grubość poszczególnych warstw \\
\hline \multirow{2}{*}{ Niski } & obrzutka & ok. $0,5 \mathrm{~cm}$ \\
\cline { 2 - 3 } & tynk renowacyjny & $\geq 1,0 \mathrm{~cm}$ \\
\hline \multirow{2}{*}{ Średni } & obrzutka & ok. $0,5 \mathrm{~cm}$ \\
\cline { 2 - 3 } & tynk renowacyjny & $2,0 \mathrm{~cm}$ \\
\hline \multirow{2}{*}{ Wysoki } & obrzutka & ok. $0,5 \mathrm{~cm}$ \\
\cline { 2 - 3 } & tynk podkładowy & $\geq 1,0 \mathrm{~cm}$ \\
\cline { 2 - 3 } & tynk renowacyjny & $2,0 \mathrm{~cm}$ \\
\hline
\end{tabular}

\section{Rzeszów - Stary Rynek}

Historia Rzeszowa nieodzownie związana jest ze Starym Rynkiem, który od początku swojego istnienia (1354r.) stanowi centrum kultury i handlu. Rola Rzeszowa jako punktu wymiany dóbr wynikała z jego usytuowania. Krzyżowały się tu lądowe szlaki handlowe, dodatkowym atutem była bliskość rzeki Wisłok.

Początkowo lokalizacja Starego Rynku była kwestią problematyczną ze względu na istnienie dwóch, a nawet trzech grodów. Ostatecznie Rynek usytuowano na lessowym wzgórzu znajdującym się pomiędzy nimi [4].

Kamienice znajdujące się w rynku wybudowane zostały na przełomie wieków. W roku 1591, ówczesny gospodarz miasta ufundował ratusz, który znajdował się w miejscu obecnego. W owych czasach zabudowa rynku miała charakter drewniany z murowanymi piwnicami [7]. Pierwsze kamienice wybudowane metodą tradycyjną (z cegły) datuje się na I połowę XVII wieku [8]. Kolejne stulecie charakteryzowało się bardzo ścisłą zabudową realizowaną według projektów nadwornych architektów, którzy mając na uwadze bezpieczeństwo pożarowe kierowali się zakazem wznoszenia wysokich dachów. Wygląd rynku wraz z wystrojem elewacji kamienic określony został na przełomie XIX i XX w. Wartym podkreślenia jest fakt, iż $\mathrm{w}$ miejscu obecnego wejścia do podziemi znajdowały się dwie kamienice, które zostały wyburzone przez nazistów w okresie okupacji [9]. 


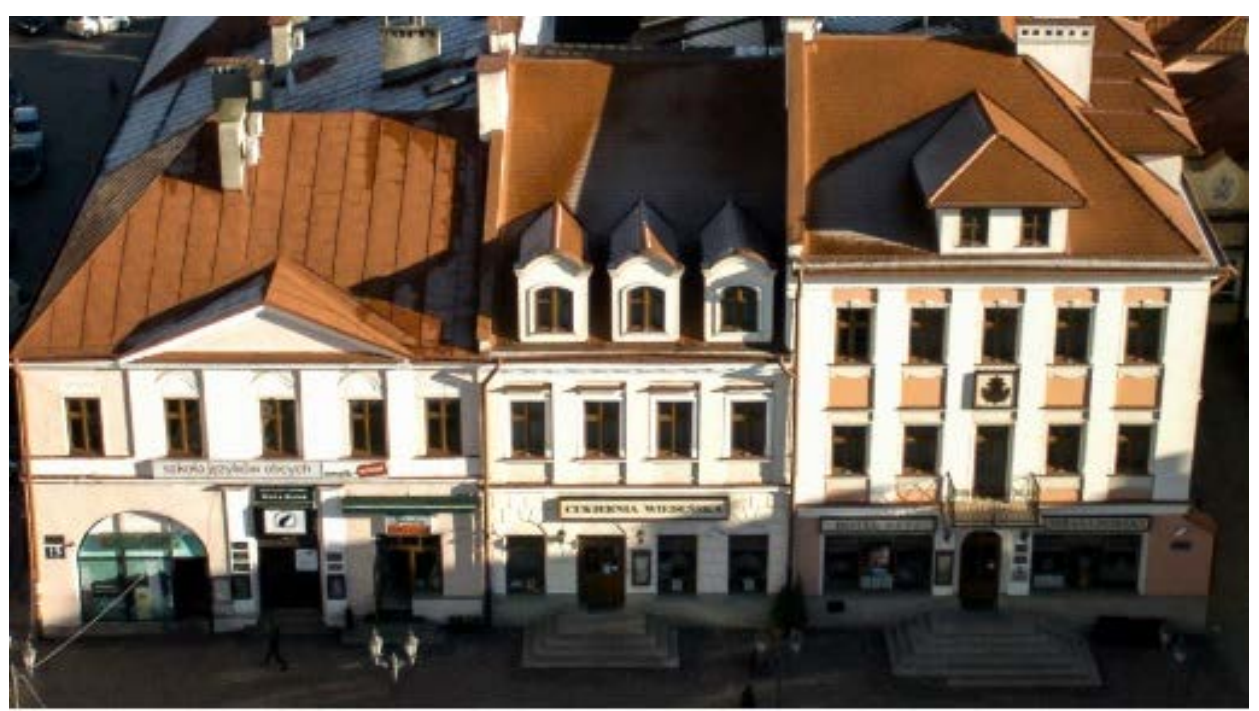

Rys. 1. Pierzeja zachodnia, fot. http://rynek.rzeszow.pl, dostęp 02.2017

Fig. 1. Western frontage, fot. http://rynek.rzeszow.pl, access 02.2017

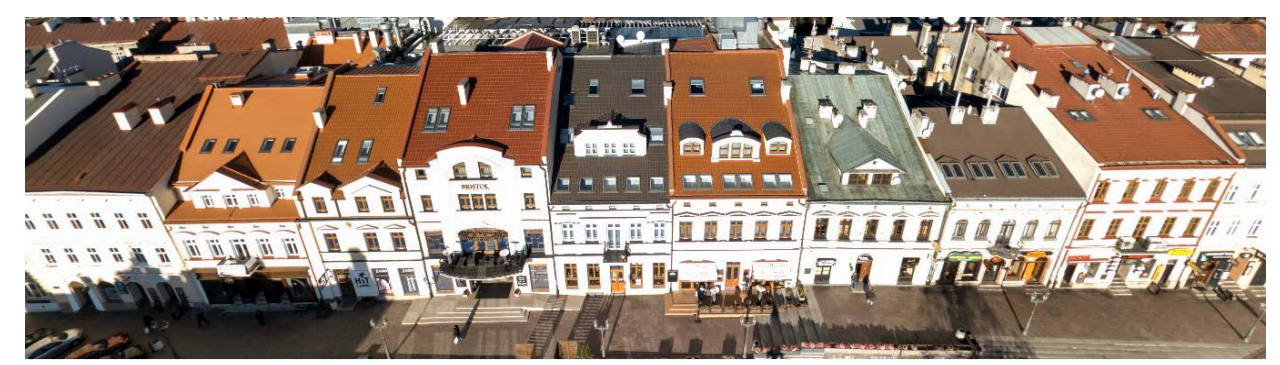

Rys. 2. Pierzeja południowa, fot. http://rynek.rzeszow.pl, dostęp 02.2017

Fig. 2. Southern frontage, fot. http://rynek.rzeszow.pl, access 02.2017

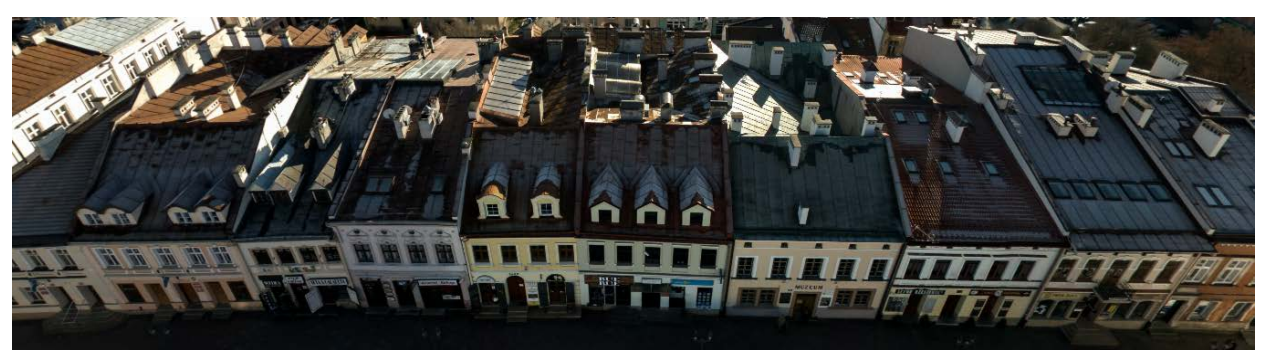

Rys. 3. Pierzeja północna, fot. http://rynek.rzeszow.pl, dostęp 02.2017

Fig. 3. Northern frontage, fot. http://rynek.rzeszow.pl, access 02.2017 


\section{Badania}

Kamienice stanowiące zabudowę rzeszowskiego Starego Rynku w przeciągu ostatnich lat poddane zostały naprawom ukierunkowanym na poprawę ich stanu technicznego poprzez wzmocnienie i zabezpieczenie konstrukcji. W zakres prac związanych z zabezpieczeniem zaliczyć należy wykonanie izolacji chroniących elementy konstrukcji przed naporem wód zewnętrznych oraz tynków renowacyjnych umożliwiających odprowadzanie uprzednio zgromadzonej wilgoci, a także akumulacji soli budowlanych. Obiekty, w których zastosowano tynki renowacyjne powinny wykazywać niższy poziom zawilgocenia, nawet w przypadku wadliwie wykonanych izolacji poziomych.

W ramach przeprowadzonych badań, kierując się chęcią sprawdzenia celowości zastosowanych tynków, wykonano serię odczytów poziomów wilgotności. Wyniki zestawiono w postaci tabelarycznej, dla każdej kamienicy z osobna $\mathrm{z}$ uwzględnieniem zastosowanego pokrycia elewacji.

Tabela 3. Pierzeja północna - Stary Rynek w Rzeszowie

Table 3. Northern frontage - Old Square in Rzeszów

\begin{tabular}{|c|c|c|}
\hline Nr kamienicy & Rodzaj pokrycia elewacji & Stopień zawilgocenia \\
\hline 3. & okładzina $\mathrm{z}$ cegły & brak / danych \\
\hline 4. & $\begin{array}{l}\text { styropian }+ \\
\text { tynk cienkowarstwowy }\end{array}$ & $\begin{array}{l}\text { cokół } 19,2 \% \\
\text { ościeżnica } 14,0 \%\end{array}$ \\
\hline 5. & cementowo - wapienny & $\begin{array}{l}\text { ściana } 11,2 \% \\
\text { cokół } 15,9 \%\end{array}$ \\
\hline 6. & cementowo - wapienny & $\begin{array}{l}\text { ściana: częściowo odparzona } \\
\text { częściowo } 8,5 \% \\
\text { okno ościeżnica } 16,3 \% \\
\text { drzwi ościeżnica } 18,2 \%\end{array}$ \\
\hline 7. & $\begin{array}{l}\text { styropian }+ \\
\text { tynk cienkowarstwowy }\end{array}$ & $\mathrm{b} / \mathrm{d}$ \\
\hline 8. & cementowo - wapienny & ściana $10,7 \%$ \\
\hline 9. & cementowo - wapienny & $\begin{array}{l}\text { ściana: częściowo odparzona } \\
\text { częściowo do } 6,2 \% \\
\text { cokół: częściowo odparzony } \\
\text { częściowo } 10,5 \%\end{array}$ \\
\hline 10. & cementowo - wapienny & ściana $11,1 \%(\max .11,5 \%)$ \\
\hline 11. & $\begin{array}{l}\text { tynk renowacyjny do wyso- } \\
\text { kości } 1 \mathrm{~m} \\
\text { tynk cementowo - wapienny } \\
\text { powyżej } 1 \mathrm{~m}\end{array}$ & $\begin{array}{l}\text { ściana: } \\
\text { do wysokości 1m 6,5\% } \\
\text { (max. 6,9\%) } \\
\text { powyżej 1m 12,3\% (max } \\
12,5 \%) \\
\end{array}$ \\
\hline 12. & $\begin{array}{l}\text { tynk renowacyjny do wyso- } \\
\text { kości } 1 \mathrm{~m} \\
\text { tynk cementowo - wapienny } \\
\text { powyżej } 1 \mathrm{~m}\end{array}$ & $\begin{array}{l}\text { ściana: } \\
\text { do wysokości 1m 5,2\% } \\
\text { powyżej } 1 \mathrm{~m} 12,2 \% \\
(\max .13,2 \%)\end{array}$ \\
\hline
\end{tabular}


Tabela 4. Pierzeja zachodnia - Stary Rynek w Rzeszowie

Table 4. Western frontage - Old Square in Rzeszów

\begin{tabular}{|c|c|c|}
\hline Nr kamienicy & Rodzaj pokrycia elewacji & Stopień zawilgocenia \\
\hline 13. & tynk renowacyjny & $\begin{array}{l}\text { ściana } 3,3 \%(\max .3,5 \%) \\
\text { cokół } 18,5 \%\end{array}$ \\
\hline 14. & tynk renowacyjny & $\begin{array}{l}\text { ściana } 3,5 \%(\max .4,2 \%) \\
\text { cokół odparzony } \\
\text { ościeżnica drzwi 12,0\% } \\
\text { (farba olejna) }\end{array}$ \\
\hline 15. & cementowo - wapienny & $\begin{array}{l}\text { ściana: częściowo } \\
\text { odparzona } \\
\text { częściowo 10,1\% (max. } \\
10,7 \%)\end{array}$ \\
\hline
\end{tabular}

Tabela 5. Pierzeja południowa - Stary Rynek w Rzeszowie

Table 5. Southern frontage - Old Square in Rzeszów

\begin{tabular}{|c|c|c|}
\hline Nr kamienicy & Rodzaj pokrycia elewacji & Stopień zawilgocenia \\
\hline 16. & cementowo - wapienny & $\begin{array}{l}\text { ściana: częściowo } \\
\text { odparzona } \\
\text { częściowo do 5,9\% } \\
\text { cokół } 14,2 \%\end{array}$ \\
\hline 17. & cementowo - wapienny & $\begin{array}{l}\text { ściana } 8,5 \% \\
\text { cokół } 6,0 \% \\
\text { ościeżnica drzwi 12,0\% } \\
\text { (farba olejna) }\end{array}$ \\
\hline 18. & cementowo - wapienny & $\begin{array}{l}\text { ściana: częściowo } \\
\text { odparzona } \\
\text { częściowo } 12,0 \% \\
\text { ościeżnica } 11,6 \%\end{array}$ \\
\hline 19. & tynk renowacyjny & ściana: 3,9\% $(\max .4,6 \%)$ \\
\hline 25. & cementowo - wapienny & $\begin{array}{l}\text { ściana: częściowo } \\
\text { odparzony częściowo } \\
11,9 \%(\max .13,0 \%) \\
\text { drzwi } 12,2 \%\end{array}$ \\
\hline
\end{tabular}

\section{Wnioski}

Podstawowym zagadnieniem związanym z przeprowadzonymi badaniami było określenie przydatności tynków stosowanych podczas prac naprawczych. Cechą wskazującą na poprawność zastosowanych rozwiązań systemowych był poziom zawilgocenia elewacji. Otrzymane wyniki porównano z normowymi wymogami, które przedstawiono w tabeli nr 6 . 
Tabela 6. Klasyfikacja murów ze względu na poziom zawilgocenia. Renowacja budynku mieszkalnego wielorodzinnego przy ul. Ks. Jałowego 5 w Rzeszowie

Table 6. Classification of wall dampness. Renovation of residential building located at Ks. Jałowego 5 in Rzeszów

\begin{tabular}{|c|c|c|}
\hline Lp. & Stopień zawilgocenia [\%] & Klasyfikacja muru \\
\hline I & $0-3$ & $\begin{array}{c}\text { mury o dopuszczalnej } \\
\text { wilgotności }\end{array}$ \\
\hline II & $3-5$ & $\begin{array}{c}\text { mury o podwyższonej } \\
\text { wilgotności }\end{array}$ \\
\hline III & $5-8$ & mury średnio wilgotne \\
\hline IV & $8-12$ & mury mocno wilgotne \\
\hline V & $>12$ & mury mokre \\
\hline
\end{tabular}

Na badanych obiektach w większości przypadków stwierdzono obecność tynków cementowo wapiennych. Zaznaczyć należy, iż jedynie na 5 spośród 18 uwzględnionych obiektów referencyjnych zanotowano obecność tynków renowacyjnych (dwa z nich wykonano w sposób mieszany tj.: przy użyciu tynków renowacyjnych, do wysokości $1 \mathrm{~m}$ nad poziomem terenu, w połączeniu z tynkami cementowo - wapiennymi na wyższych partiach elewacji). Elewacja kamienicy $\mathrm{nr} 3$ wykonana jest z cegły, natomiast elewacje kamienic $\mathrm{nr} 4$ i 7 wykonano poprzez zastosowanie styropianu pokrytego tynkiem cienkowarstwowym, do czego odniesiono się w dalszej części artykułu.

Na obiektach, których elewacje wykonano z tynków cementowo - wapiennych zachodzą procesy wynikające $\mathrm{z}$ ograniczonej dyfuzji wilgoci, co bezpośrednio prowadzi do odparzania, a następnie odpadania płatów tynku. Podkreślić należy, iż odparzenia znacząco wpływają na zakłócenie odczytu wilgotności, co spowodowane jest pustkami powstającymi w strefie przypowierzchniowej muru. Zjawisko to należy tłumaczyć wysoką zawartością cementu na co jednoznacznie wskazuje charakterystyczny ciemny kolor tynku.

W przypadku zastosowania tynków renowacyjnych stwierdzono obniżony poziom zawilgocenia murów. Rzeczą wartą podkreślenia jest fakt, iż wszystkie badane elewacje wykazują poziom zawilgocenia przekraczający normowe progi określające jego stan jako dopuszczalny. Sytuacja, w której poziom zawilgocenia wskazuje na mur o podwyższonej wilgotności (nie przekracza poziomu 5\% zawilgocenia) może być uznana za dopuszczalną ze względu na kontakt elewacji ze środowiskiem zewnętrznym. Stan taki zaobserwowano na kamienicach nr 13 $(3,3 \%), 14(3,5 \%)$ oraz $19(3,9 \%)$. Zawilgocenie dochodzące do poziomu 5\% może świadczyć o wcześniejszej bardzo dużej wilgotności muru, wadliwie wykonanym tynku renowacyjnym lub zastosowaniu słabo dyfuzyjnych farb. Dodatkowo zawilgocenie nie przekraczające 5\% świadczyć może o skutecznej izolacji.

Wpływ doboru systemu renowacji na późniejszy stan i trwałość elewacji widoczny jest na przykładzie kamienic nr 11 i 12 gdzie zastosowano tynk renowacyjny do wysokości 1,0m, a powyżej tynk cementowo - wapienny. Poziom za- 

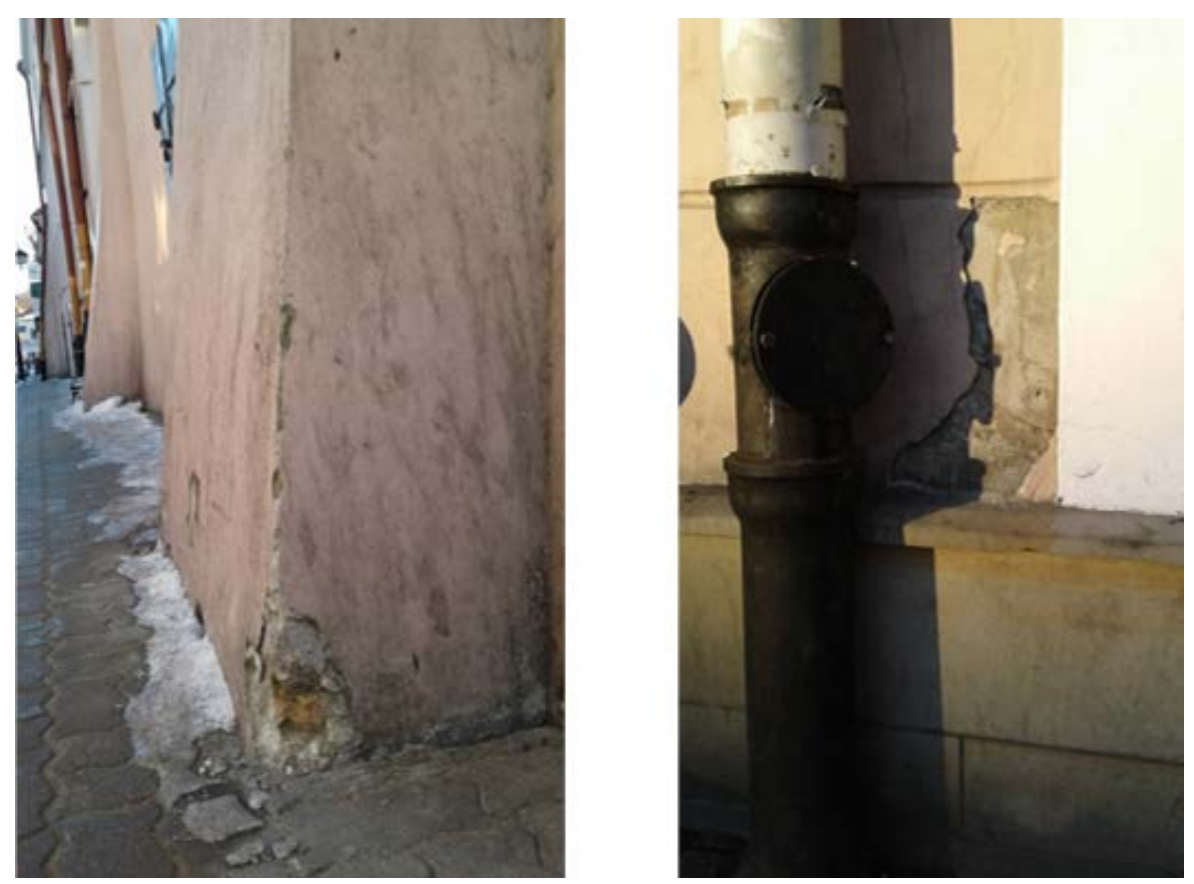

Rys. 4. Korozja tynku, fot. autor, Luty 2017

Fig. 4. Degradation of plaster, fot. author, February 2017

wilgocenia tynków renowacyjnych w obu przypadkach przekracza wartość 5\%, co świadczy o braku skutecznej izolacji poziomej muru. Różnica poziomów zawilgocenia pomiędzy poszczególnymi strefami (tynk renowacyjny, a cementowo - wapienny) wynosi ok. 6\%. Dwukrotnie wyższy poziom zawilgocenia w strefie tynku cementowo - wapiennego wywołany jest różnicą w strukturze, warunkującą głównie zmniejszenie powierzchni porów i niższą dyfuzyjność.

Praktyka wskazuje, że po wykonaniu izolacji poziomej oraz prawidłowego systemu renowacji muru, wilgoć po okresie 3 lat od ich wykonania, powinna spaść do poziomu dopuszczalnego.

Korzystny wpływ tynku renowacyjnego widoczny jest na kamienicach 13 i 14, których ściany w porównaniu ze strefą cokołową wykazują nawet 6 krotnie niższe zawilgocenie. Świadczy to o wysokiej dyfuzyjności tynku z jednoczesną zdolnością do akumulacji soli budowlanych wewnątrz jego struktury.

Widoczne na poniższym zdjęciu uszkodzenia strefy cokołowej świadczą o braku skutecznej izolacji poziomej oraz błędach wykonawczych polegających na klejeniu kamiennej okładziny bezpośrednio na wysoce zawilgoconej ścianie (zawilgocenie cokołów sięga poziomu 18\% - mur mokry). Pamiętać należy, iż piaskowiec jest materiałem, który ze względu na swoją strukturę mocno chłonie wodę. Nie poddany odpowiednim zabiegom impregnacyjnym skoroduje. 


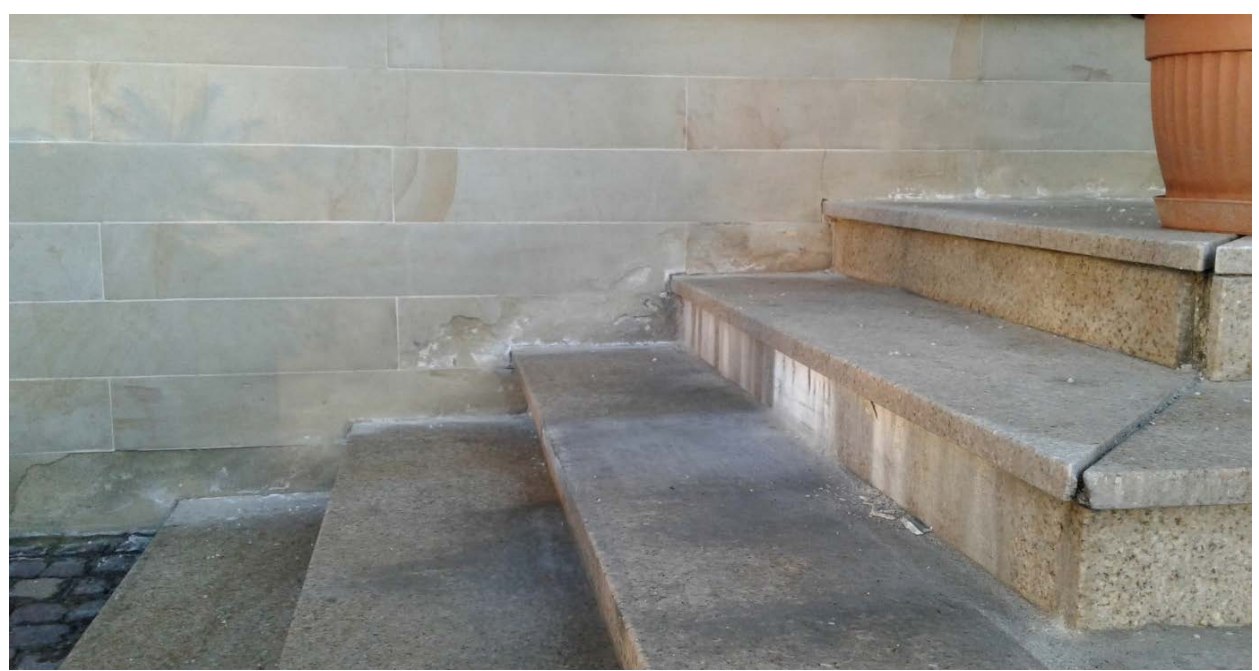

Rys. 5. Korozja cokołu, fot. autor, Luty 2017

Fig. 5. Corrosion of pedestal, fot. author, February 2017

Brak tynku renowacyjnego stwierdzono również na ościeżnicach i gzymsach kamienic nr 13 i 14. Warto pamiętać, iż gzymsy, jako elementy ciągłe bardzo często wykonywane są z zaprawy cementowej co w połączeniu z niewłaściwą okładziną doprowadzi do odspajania nałożonego tynku bądź wyprawy malarskiej. Zjawisko to zilustrowane zostało na fotografii $\mathrm{nr} 7$.

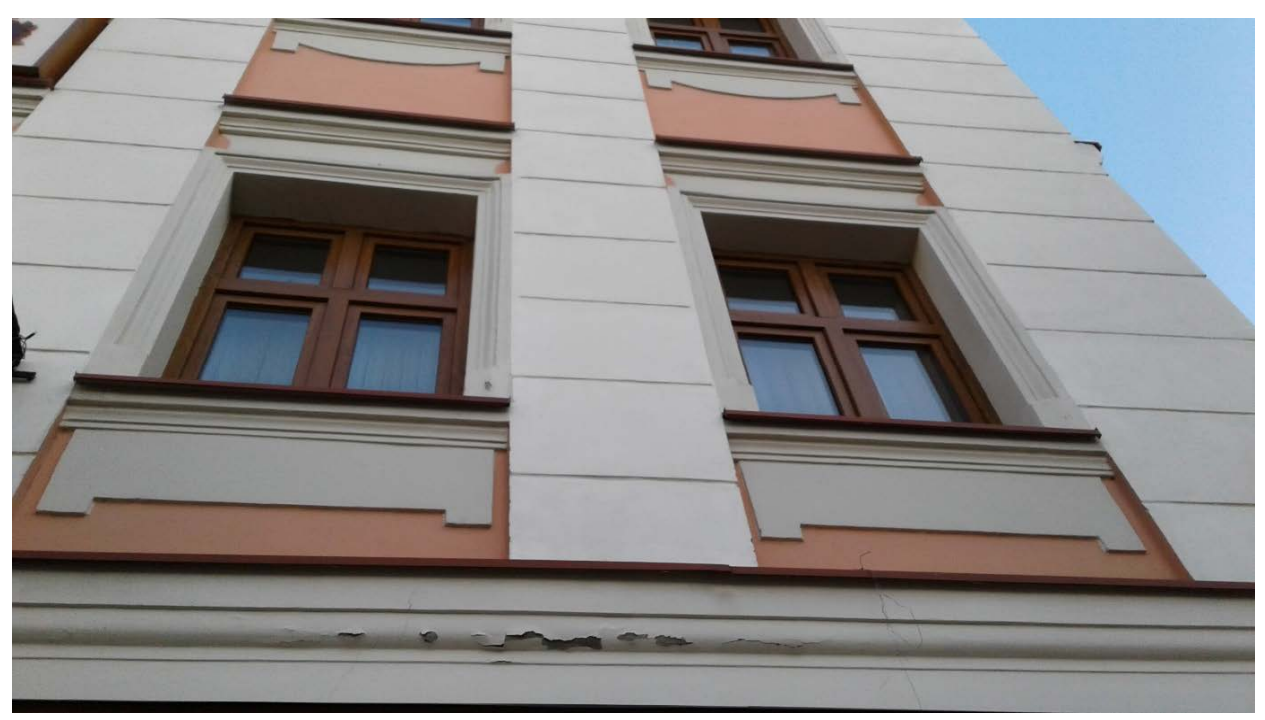

Rys. 6. Uszkodzony gzyms, fot. autor, Luty 2017

Fig. 6. Degradation of mantelpiece, fot. author, February 2017 
Kamienica nr 13 jest również przykładem błędu wykonawczego polegającego na zbyt mocnym dociskaniu szpachli. Zacieranie „na gładko” obniża estetykę elewacji, a co gorsze powoduje kondensację spoiwa na powierzchni tynku. Wynikiem takich działań jest pojawienie się rys skurczowych i obniżenie dyfuzyjności [6].

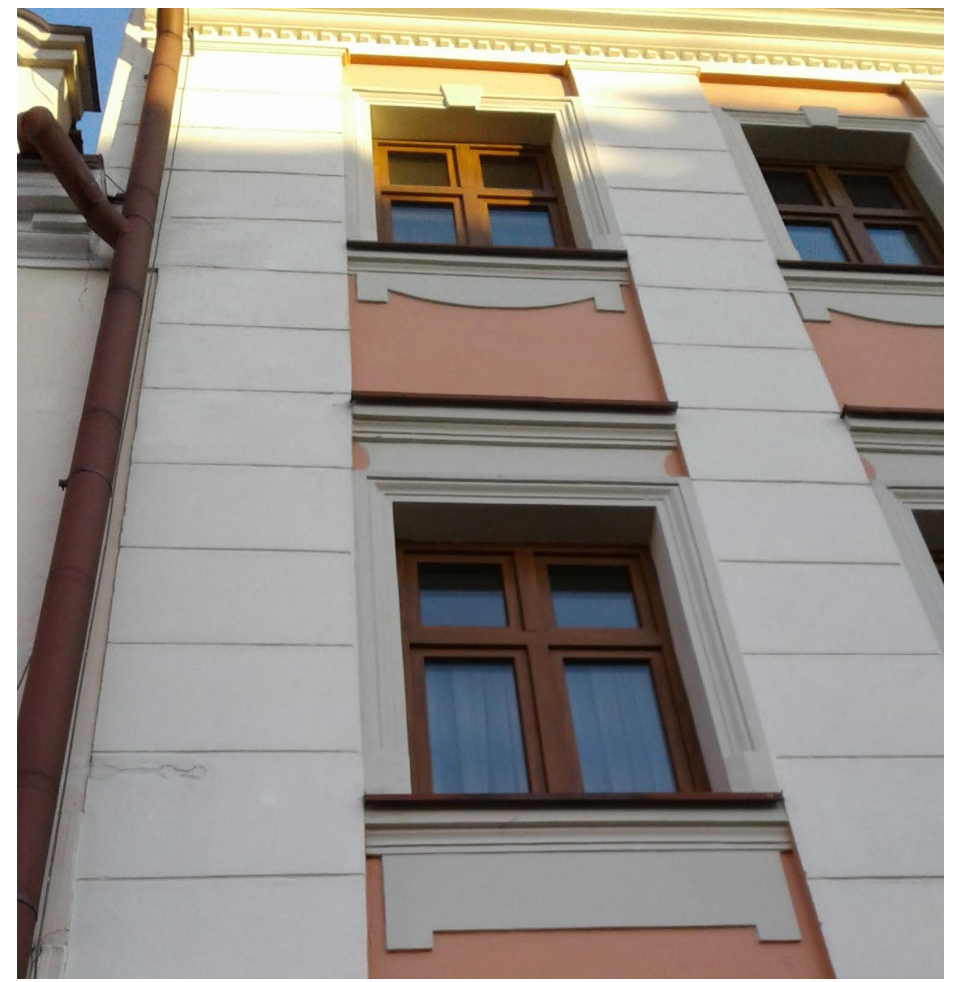

Rys. 7. Zatarcie na gładko, fot. autor, Luty 2017

Fig. 7. Inappropriate accomplishment of plaster, fot. author, February 2017

Złym nawykiem jest uzupełnianie skorodowanego tynku poprzez nanoszenie materiałów różniących się charakterystyką w stosunku do tynku istniejącego. Niedopuszczalnym jest stosowanie materiałów o niskiej paroprzepuszczalności, przykładowo szpachli cementowych. [6]

Ważnym czynnikiem, decydującym o prawidłowym funkcjonowaniu systemu tynków renowacyjnych jest stosowanie farb o możliwie najniższym oporze dyfuzyjnym i współczynniku przenikania wody. Spośród dostępnych na rynku farb, najodpowiedniejszą, w przypadku obiektów uprzednio zawilgoconych, jest farba sylikatowa (czysta farba krzemianowa). 


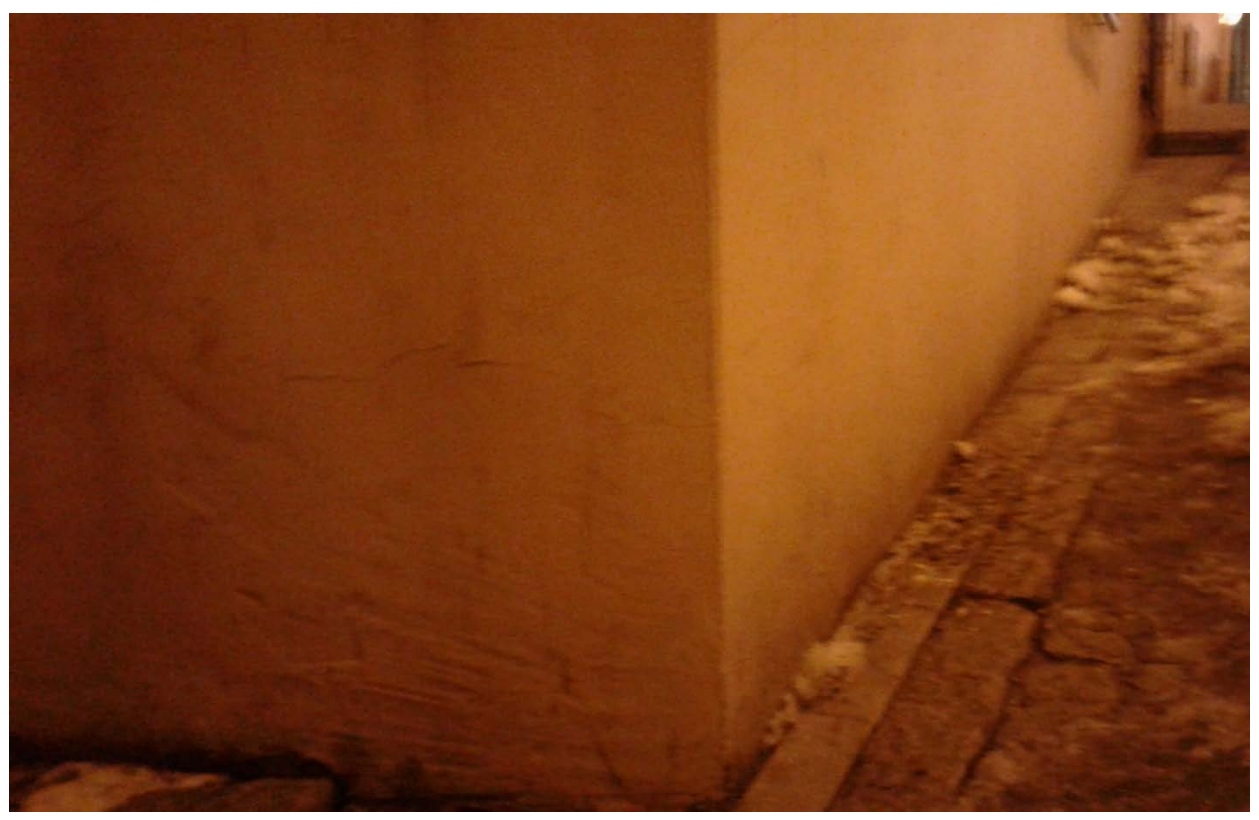

Rys. 8. Nieprawidłowe uzupełnienie skorodowanego tynku, fot. autor, Luty 2017

Fig. 8. Inappropriate way of fixing the plaster, fot. author, February 2017

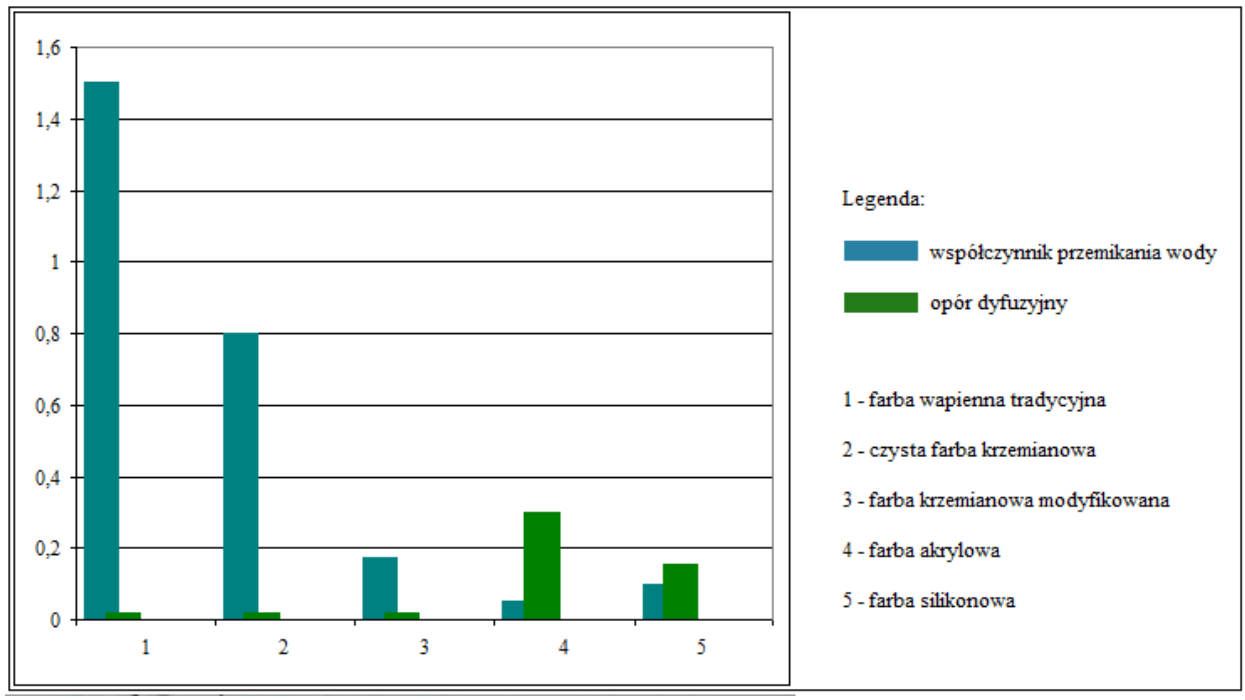

Rys. 9. Zależność między współczynnikiem dyfuzji pary wodnej, a nasiąkliwością farb, fot. autor, Luty 2017

Fig. 9. Dependence of paint characterization, fot. author, February 2017 
Rozwiązaniem, które wraz z upływem czasu spowoduje wzrost zawilgocenia elementu jest stosowanie farb akrylowych. Charakteryzują się one znikomą paroprzepuszczalnością (duży opór dyfuzyjny). Przykładem potwierdzającym teorie jest stan kamienicy nr 17, której ośceiżnice są bardzo mocno zawilgocone $(12 \%)$.

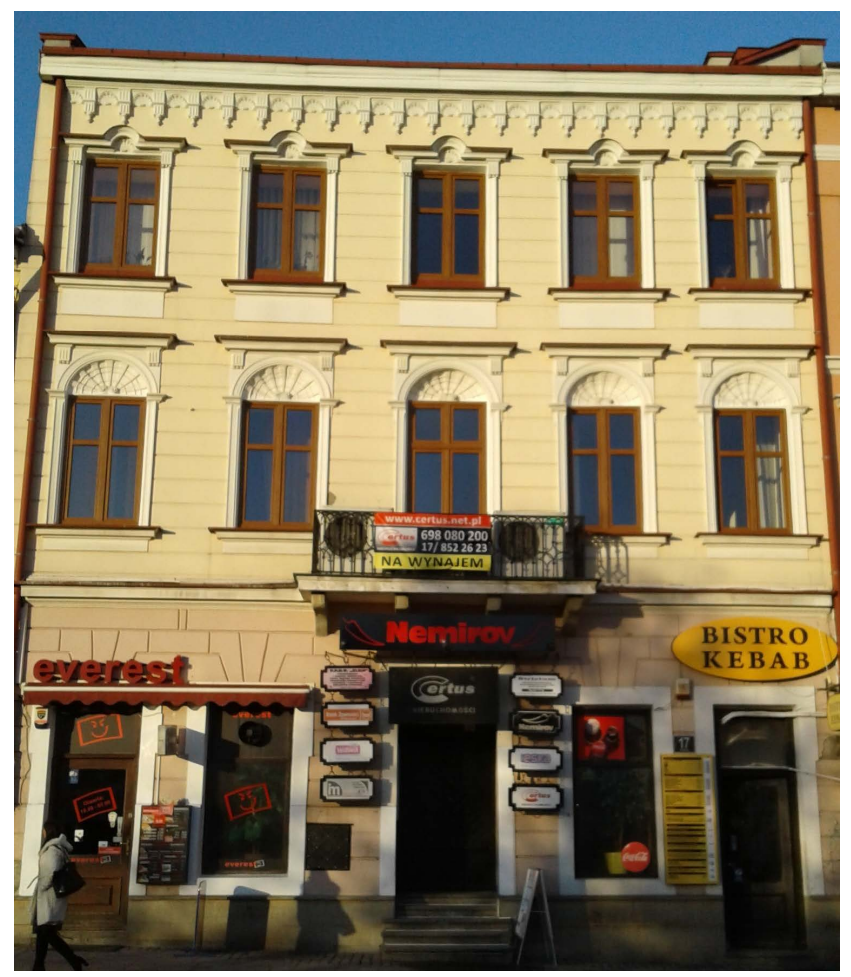

Rys. 10. Kamienica nr 17, fot. autor, Luty 2017

Fig. 10. Tenement house number 17, fot. author, February 2017

Znajdująca się w rynku kamienica nr 4 jest przykładem wadliwej konstrukcji warstw elewacji. Pokrycie ściany styropianem powoduje podwyższenie strefy podciągania kapilarnego, a w związku z tym wzmożone zawilgocenie $\mathrm{w}$ wyższych partiach muru. Poziom zawilgocenia strefy cokołowej $(19,2 \%)$ wskazuje na brak izolacji poziomej i jest przyczyną odparzania warstw pokrycia elewacji. Podobna sytuacja ma miejsce w przypadku kamienicy nr 17 (strefa cokołowa $6 \%$, ściana $8,5 \%$ ). 


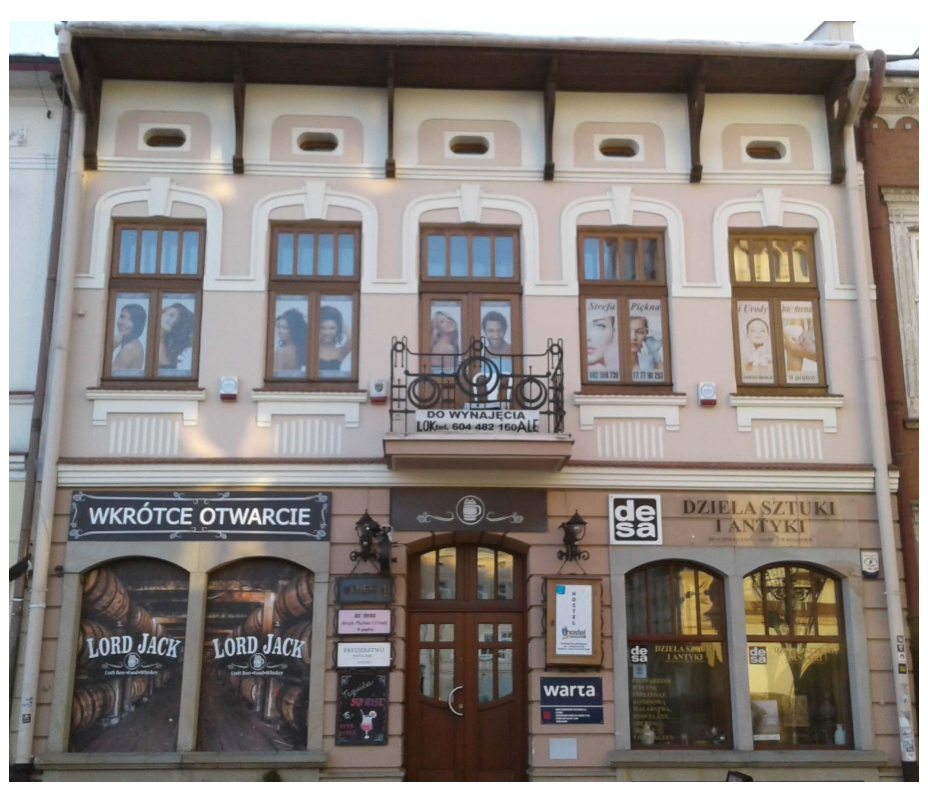

Rys. 11. Kamienica nr 4, fot. autor, Luty 2017

Fig. 11. Tenement house number 4, fot. author, February 2017

\section{Podsumowanie}

Przeprowadzone badania jednoznacznie wskazują, iż słusznym rozwiązaniem w przypadku usuwania zawartości wilgoci z murów obiektów zabytkowych jest stosowanie tynków renowacyjnych posiadających atest organizacji Naukowo-Technicznej Grupy Roboczej ds. Utrzymania Budowli i Ochrony Zabytków. Wszelkie inne rozwiązania mają charakter tymczasowy. Stosowanie nieodpowiednich rozwiązań systemowych doprowadza do pogorszenia stanu technicznego elewacji, co bezpośrednio wpływa na obniżenie walorów estetycznych obiektu oraz na wzrost kosztów eksploatacji. Dodatkowo pamiętać należy, iż tynki renowacyjne nie są złotym środkiem i bez uprzedniego wykonania izolacji poziomej przegrody, wpływ destrukcyjnego działania wód zostanie jedynie tymczasowo zahamowany.

\section{Literatura}

[1] Hölzen F-J.: Renowacja przy problemach wynikających z zasolenia i wilgoci, B+B 2009.

[2] Pluta A., Pluta K.: Tynki w budownictwie cz.I., Inżynier budownictwa 2014.

[3] Rokiel M., Magott C.: Tynki renowacyjne, Inżynier budownictwa 2012.

[4] Kotula F.: Tamten Rzeszów. Libri Ressovienses, Rzeszów, 1997. 
[5] PCI. Systemy PCI do renowacji i izolowania zawilgoconych budynków, BASF Polska, Śrem, 2016.

[6] Rokiel M.: Poradnik. Hydroizolacje w budownictwie, Medium, Warszawa, 2006.

[7] Borowiejska-Birkenmajerowa M.: Rozwój przestrzenny miasta za Mikołaja Spytka Ligęzy. W: Dzieje Rzeszowa, UM Rzeszów, Rzeszów, 1994.

[8] Malczewski J.: Zabudowa mieszczańska. W: Dzieje Rzeszowa, UM Rzeszów, Rzeszów, 1994.

[9] Rzeszów dawniej i dziś - Rynek Główny, http://mariten.blog.onet.pl/ (dostęp: 19.02.2017).

[10] Sikorski K.: Renowacja budynku mieszkalnego wielorodzinnego przy ul. Ks. Jałowego 5 w Rzeszowie, Praca inż., Politechnika Rzeszowska, 2015.

\title{
OLD MARKET IN RZESZOW - PLASTERS USED DURING RESTORATION WORKS OF HISTORICAL BUILDINGS. TECHNOLOGICAL ASPECTS
}

\begin{abstract}
S u m m a r y
The market is a place with significant cultural advantages and his state is a proff of potential and the rank of city or town. Due to that fact, attenition is being put to aesthetics of frontal elevation of tenement houses located around the historical square. Quality od performed work and materials used in renovation has main influance on technical condition of front elevations. Renovation issue is strongly connected with diagnosis, repair and usage solution of building. In the article attention is being paid to the appropriateness of applied covers of elevation on the example of the Rzeszów Old Square (buildings were fixed in past few years). Few kinds of plaster were put under consideration (lime plaster, cement plaster, lime and cement plaster, renovation plaster). According to examinations of current state of referentail buildings conclusions were made. Only renovation plaster enabled to fulfil design assumptions, i.e.: influenced on lowering the moisture of walls. Indisputable advantage of renovation plaster (resulting from their composition and the structure) is ability to accumulate melted minerals inside plaster leeks what makes them more permanent (plaster coming off from the surface of a wall has not been stated). Additionally the issues of performation of renovation works and influecne of materials quality were brought up.
\end{abstract}

Keywords: Rzeszow, Old Market, renovation plaster, dampness, salinity

Przestano do redakcji: $2.10 .2017 \mathrm{r}$.

Przyjęto do druku: 15.12.2017 r. 